Z Badań nad Książką i Księgozbiorami Historycznymi 2021, t. 15, z. 4

\author{
Ryszard Nowicki \\ Kazimierz Wielki University in Bydgoszcz, \\ Bydgoszcz, Poland \\ rnowicki@ukw.edu.pl
}

(iD) 0000-0001-8507-2086

https://doi.org/10.33077/uw.25448730.zbkh.2021.687

\title{
Legal regulations concerning the preservation and protection of library collections in Poland after World War II
}

\begin{abstract}
The article presents the problem of the practical application of legal regulations related to the preservation and protection of written cultural heritage in Poland after World War II, within the borders of 1945. The first legislative initiatives were undertaken in 1944. The introduction of normative provisions was initiated on a patch of Polish territory free from the German occupant. The war events, changes in the shape of the country's borders and the political system made it necessary to develop national documents in order to protect library collections, regardless of their origin. It was not an easy task to implement due to numerous difficulties and a complicated post-war reality. Based on few legislative provisions, over ten million volumes, mostly of post-German provenance, were saved until 1949. Valuable written materials were used to partially compensate for the World War II losses, rebuild libraries and Polish librarianship.
\end{abstract}

Key words: protection - library collections - law - Poland $-20^{\text {th }}$ century 


\section{Introduction}

The war and war-related events caused enormous destruction of Polish written cultural heritage. According to estimated data, losses in western and central Poland amounted to approximately $71 \%$ of total collections, while scientific and professional libraries lost approximately $45 \%$ of their collections during World War $\mathrm{II}^{1}$. Numerous library collections, or their fragments, were moved over long distances. Some of the works stolen by the Germans from European countries were transported to Poland during the war and occupation. This happened to, for example, the Masonic collection, confiscated books from political organizations and left-wing parties. During the war, to safeguard the most valuable collections of the Preussischer Staatsbibliothek against the expected bombing of Berlin, the Germans transported them to Lower Silesia. Works by Johann Sebastian Bach, Ludwig van Beethoven, Wolfgang Amadeus Mozart, Franz Schubert, and Robert Schumann were among those transported from the capital of the Third Reich ${ }^{2}$. On a national scale, especially Lower Silesia abounded in numerous post-German book collections. Many collections of this provenance survived in Szczecin Pomerania, where Polish books were not present. In legal terms, Poland was not prepared to undertake organized activities regarding protection of written cultural heritage. There were no relevant legal regulations. They had to thus be developed and implemented. There were many difficulties, including the lack of coordination of activities. Various ministries, school authorities, institutions, the army, representatives of state administration, political parties, social and self-government organizations conducted activities independently. The situation changed at the beginning of 1945. All matters related to libraries, including the protection of written materials, were subordinated to the Ministry of Education, established on January 1, 1945. An internal order of the Ministry of Education, established on March 12, 1946, the Chief Directorate of Libraries (Naczelna Dyrekcja Bibliotek; NDB) which was headed, since April 1, 1946, by the chief director Józef Grycz. The main tasks of the NDB included securing, reclaiming and distribution of library collections. According to J. Grycz's plan ${ }^{3}$, activities related to saving the written sources were carried

1 A. Mężyński, Z dziejów bibliotek w Polsce. Od średniowiecza do 1989 roku, Warszawa 2017, p. 57.

2 R. Nowicki, Rola katowickiej Zbiornicy Ksiegozbiorów Zabezpieczonych w powojennej ochronie zbiorów bibliotecznych w Polsce, Bydgoszcz 2015, p. 33.

3 R. Nowicki, Rola Józefa Grycza w powojennej ochronie zbiorów bibliotecznych, "Z Badań nad Książką i Księgozbiorami Historycznymi” 2011, vol. 5, pp. 89-108; idem, Protection of written heritage after World War II. Józef Grycz's contribution to saving library collections, "Studies into the History of the Book and Book Collections" 2019, special issue: For an Independent Poland, pp. 191-206. 
out in Poland in a planned and organized manner until 1949. In 1945, the co-organizer of Polish librarianship ${ }^{4}$ published a book entitled Wskazówki dla prowadzacych akcję zabezpieczenia bibliotek $i$ zbiorów bibliotecznych (Guidelines for preserving libraries and library collections) ${ }^{5}$, in which he raised the issue of legislative documents. Attempts to refer to legal provisions of the interwar period, i.e. the years 1918-1939, did not produce any effects and were only temporary. At that time, there was no need to take legislative actions with regard to collections requiring protection on such a large scale. The victorious Polish-Russian war of 1919-1920 made it possible to recover some of the written materials stolen during the partitions of Poland by Russia. As a result of the Treaty of Riga, signed on March 18, 1921, which ended the war, a part of the lost collections returned to the country ${ }^{6}$.

After World War II, the state authorities did not recognize the protection and preservation of library collections as a priority. The priority was to rebuild the economically devastated country. One of the important tasks of this period was the creation of a network of public libraries including educational, school and research libraries. Books were to serve all citizens and access to libraries was to be public. Numerous book collections were nationalized and became the property of the Treasury. Pursuant to the first Polish law on libraries of April 17, 1946, libraries and library collections were recognized as "national cultural property, established to serve the common good" ". Book collections in Poland were vulnerable to physical destruction and looting. The rightful owners of the collections, i.e. the landowners, lost their property rights due to political reasons. In Western and Northern Poland, post-German collections, which had been there for centuries, as well as those moved there by the Nazi authorities during the war and occupation, survived. Thus, on a national scale, there was an urgent need to protect books, regardless of their provenance. Nobody had the relevant experience which had to be gained in practice. The most important legislative regulations concerning the preservation and protection of library collections were developed by J. Grycz.

The only way to determine the effects of the legislative regulations is to combine the analysis of legal documents with the examination

4 See: A. Mężyński, Józef Grycz (1890-1954) organizator polskiego bibliotekarstwa, Warszawa 2020.

5 J. Grycz, Wskazówki dla prowadzących akcję zabezpieczenia bibliotek i zbiorów bibliotecznych, Warszawa-Poznań 1945.

6 D. Pietrzkiewicz, Spory o zbiory. Piotr Bańkowski - rewindykacja i ochrona dziedzictwa piśmienniczego, Pułtusk-Warszawa 2019.

7 Dekret z dnia 17 IV 1946 r. o bibliotekach i opiece nad zbiorami bibliotecznymi, "Dziennik Ustaw" 1946, no 26, pos. 163. 
of manuscripts ${ }^{8}$. Normative documents were noted in Antoni Knot $^{9}$ and Tadeusz Zarzębski's ${ }^{10}$ works, and collected and published in $2013^{11}$. It was not until 2016 that the decree of the Ministry of Education appeared in print regarding the establishment of the Ministry of Education Delegation (Delegatura Ministerstwa Oświaty) in Kraków on December 1, 1945, for protection of abandoned and deserted book collections ${ }^{12}$, based on a certified copy of the document ${ }^{13}$. This situation was the result of placing the activities of the Kraków Delegation under a confidentiality clause. The article is based on the analysis of legal documents and manuscripts scattered in cultural institutions' archives across the country ${ }^{14}$.

\section{First legal regulations}

The first draft of legal regulation, agreed with the Polish government in exile in London, was developed under conspiratorial conditions in the occupied Polish territories in $1944^{15}$. However, the draft of this regulation on protection and reconstruction of library collections has never seen the daylight and was of no practical use. In 1944, the shape of post-war Poland was not known. The project assumed the creation of library districts allotted around the eight largest libraries in the country, within the borders of 1939. Among them, there were two districts outside the new borders, i.e. the University Library in Lviv and the University Library in Vilnius. There were also three districts around libraries in Warsaw - the National Library, the University of Warsaw Library and the Warsaw Public Library. At that time, no one thought that in the face of the enormous destruction of the capital, none of the Warsaw book culture

8 J. Puchalski, Źródła do historii bibliotek w Polsce w latach 1918-1947. Studium bibliologiczne, Warszawa 2007, p. 110.

9 A. Knot, Polskie prawo biblioteczne, Wrocław-Warszawa 1947.

10 T. Zarzębski, Polskie prawo biblioteczne 1773-1990, Warszawa 1991.

11 R. Nowicki, Powojenna ochrona zbiorów bibliotecznych w Polsce w latach 1944-1955. Wybór źródet, Bydgoszcz 2013.

12 R. Nowicki, Działalność krakowskiej Delegatury Ministerstwa Oświaty do zabezpieczenia księgozbiorów opuszczonych i porzuconych na Pomorzu Zachodnim, [in:] Ochrona zbiorów bibliotecznych, ed. by R. Nowicki, J. Gomoliszek, K. Wodniak, Bydgoszcz 2016, pp. 87-88.

13 Archiwum Biblioteki Jagiellońskiej w Krakowie (Archive of the Jagiellonian Library in Kraków), Archiwum Delegata Ministerstwa Oświaty do zabezpieczenia księgozbiorów opuszczonych i porzuconych. Rozporządzenia i ich odpisy 1945.

14 More information on this subject in the author's articles and monographs: Działalnośc $\mathrm{Al}$ eksandra Birkenmajera na rzecz powojennej ochrony zbiorów bibliotecznych. Ziemie zachodniej i pótnocnej Polski w latach 1945-1947, Poznań 2006; Rola Katowickiej Zbiornicy Księgozbiorów Zabezpieczonych w powojennej ochronie zbiorów bibliotecznych w Polsce, Bydgoszcz 2015.

15 R. Nowicki, Nieznany projekt rozporządzenia o zabezpieczeniu zbiorów bibliotecznych i odbudowie bibliotek w powojennej Polsce, "Z Badań nad Książką i Księgozbiorami Historycznymi" 2012, vol. 6, pp. 113-126. 
institutions would be able to undertake the planned activities. Later legislative regulations announced in 1945 and 1946 referred to the idea of dividing Poland into library districts.

The first published legal document, which contained only a reference to the protection of books, was the request of Stanisław Skrzeszewski, director of the Education Resort, to the Polish teachers on August 1, $1944^{16}$. S. Skrzeszewski appealed to teachers to encourage others, especially students and their parents, to collect textbooks, fiction and popular science literature, maps and atlases. The main idea was to start teaching, as soon as possible, using ad hoc gathered resources. Pursuant to the imposed obligation, teachers first began to rebuild the structure of education, and then, together with their students, undertook activities related to the protection of books in local communities.

The military noticed the need to save written materials. This is evidenced by the Order No 120 of the Supreme Commander of the Polish Army of November 22, $1944^{17}$. General Michał Rola-Żymierski gave an order to secure objects, including scientific books, in the areas free from Nazi occupation and liberated. Whenever possible, as stated in the document, the materials were to be transported to the Military Research and Publishing Institute in Lublin. The capital of the country, Warsaw, which at that time was still under German occupation, was not mentioned. The soldiers fighting the enemy did not have time to secure and transport books to Lublin. The priority was to defeat the Germans. Military units were changing their position with the moving line of the eastern front. After capturing Berlin, the military returned to the country, occupying the assigned area. Soldiers were informing representatives of the Ministry of Education about valuable written collections which were frequently found. The Polish military authorities cooperated with civilian authorities. In return for books, stationery for office purposes, a scarce resource, was expected. Help in transporting books to the nearest railway station was frequently offered, on condition that the appropriate amount of gasoline was provided. The shortage of this resource, shortly after the end of hostilities, was felt throughout the country. An interesting internal document, published in the form of an ephemeron, is the Order No 129 of the Military District Command No 4 in Wroclaw of May 4, 1946, on book collections and scientific book collections ${ }^{18}$. General Stanisław Popławski ordered to hand over

16 Wezwanie do nauczycielstwa polskiego, "Dziennik Urzędowy Resortu Oświaty” 1944, no $1-4$.

17 Wojskowe Biuro Historyczne - Centralne Archiwum Wojskowe w Warszawie (Military Historical Bureau - Central Military Archives in Warsaw), ref. III.5.197, p. 36, Rozkaz nr 120 Naczelnego Dowódcy Wojska Polskiego z 22 XI 1944 r.

18 Archiwum Uniwersytetu Wrocławskiego (Wrocław University Archives), Biblioteka Uniwersytecka 1945-1953, ref. R-30, p. 418. 
to the representatives of the University of Wroclaw all post-German written collections in Lower Silesia that were under the care of the military authorities or which were secured by them. A completely different attitude was displayed by numerous branches of the Soviet army stationed in Poland. During acts of war, book collections, especially in German and Latin, were frequently damaged. Part of them was transported as trophy material to the Soviet Union. Collaboration in the transfer of books was very limited. The Red Army rarely handed over the volumes collected and prepared for export to the East to the representatives of the Polish authorities.

Let us return to the legal regulations of 1944. On November 29, the circular of the Education Resort of the Polish Committee of National Liberation was published $^{19}$. It imposed an obligation on school inspectorates and school superintendents to protect and register all libraries and book collections, and to secure the collections against damage and plunder. In fact, it was the first legal regulation that began to bring tangible results in the form of a rapidly increasing number of saved volumes. School authorities, by virtue of the circular of November 29, 1944, sent internal letters to their subordinates to immediately start protecting books, regardless of their origin. Collected volumes were stored in temporary repositories, including school classrooms. With the start of classes, the classrooms had to be emptied. Therefore, it was necessary to translocate the volumes and look for new places to store books, which was not an easy task. In the field, book collections which required protection were numerous. Nevertheless, representatives of school authorities, ready to secure such collections, repeatedly learnt that the books had already been taken by delegates from other institutions, organizations, political parties and private persons. Therefore, there was a need for coordinated work, based on legal provisions, by one central body.

\section{Centralized work of the Ministry of Education}

On a national scale, centralized activities related to the protection of book collections were carried out by the Ministry of Education. S. Skrzeszewski, minister of education, during his visit to Kraków on February 15, 1945, issued the regulation concerning the protection of library collections ${ }^{20}$. The minister appointed four district library managers - the directors of the Jagiellonian

19 Okólnik Resortu Oświaty w sprawie zabepieczenia bibliotek i zbiorów bibliotecznych, Nr Bibl. IV-W-2195/44, “Dziennik Urzędowy Resortu Oświaty” 1944, no 1-4, pos. 32.

20 Archiwum Biblioteki Uniwersyteckiej w Poznaniu (Archives of the University Library in Poznań), Referat Zabezpieczenia i Segregacji Zbiorów. Zarządzenia, instrukcje, upoważnienia 1944-1946, ref. 535, p. 13 - Pismo Ministra Oświaty do Ministerstwa Rolnictwa i Reform Rolnych w Warszawie z 15 II 1945 r. 
Library in Kraków, the Public Library in Katowice, the Municipal Library in Łódź and the University Library in Poznań. The tasks of district library managers included: collecting information about existing libraries and war losses, securing all libraries, collecting scattered books, sorting volumes according to suitability for different types of libraries, agreeing on securing libraries with other authorities, including school authorities. The circular of November 29, 1944 was still in force. School authorities started cooperation with the designated heads of individual districts, informed them about the presence of book collections in the field and handed over secured books. District managers met numerous difficulties, including those resulting from the ongoing war, and could only proceed after the fighting had ceased. The matter was complicated by the lack of administrative divisions. The area assigned to the managers turned out to be too large for the limited possibilities. They did not have enough people to deliver books, there was lack of equipment and storage space for secured and transported volumes. The funds obtained from the Ministry of Education were too modest in relation to the needs. There was lack of field work experience. Therefore, the information on the methods of the protection of book collections described in J. Grycz's publication Wskazówki..., were widely used.

As mentioned earlier, books were to serve the general public. Private book collections began to be included in state collections. The so-called abandoned and deserted book collections were under protection. Pursuant to the Act of 6 May 1945 on abandoned and deserted estates ${ }^{21}$, the first group included those which, due to the war started on September 1, 1939, were not in the possession of their owners. The second group consisted of collections that were in the possession of the German state, German citizens and people who had fled to the enemy ${ }^{22}$. Donating "deserted" books to libraries did not arouse emotions. The enormous losses of Polish cultural heritage were freshly remembered. It was decided that the inclusion of the post-German collections would partially compensate for the losses incurred by Poland during the war. On the other hand, "abandoned" collections included numerous collections of former manor houses. Property rights were lost by the rightful owners as a result of political and constitutional changes. The landowners were eliminated in 1945. They could not return to their residences, where valuable book collections accumulated over several generations were located. They were not even allowed to live in the same administrative district where their former

21 Ustawa z dnia 6 V 1945 r. o majątkach opuszczonych i porzuconych, "Dziennik Ustaw" 1945, no 17, pos. 97.

22 Dekret z dnia 8 III 1946 r. o majątkach opuszczonych i poniemieckich, "Dziennik Ustaw" 1946, no 13, pos. 87. 
private estates were located. The "abandoned" book collections, unattended, were quickly depleted. In mid-1945, the Ministry of Education issued two regulations concerning taking over book collections from plenipotentiaries for land reform ${ }^{23}$ and concerning protection and usage of abandoned and deserted book collections ${ }^{24}$. These documents formed the legal basis for the seizure of "abandoned" and "deserted" collections ${ }^{25}$. Post-German books were sent mainly to scientific libraries. A special place among them was the University Library in Torun, which started its activity on June 11, 1945. At the time of its establishment, the institution did not have any collections of its own. The book collection was based on post-German collections transported with the consent of the Ministry of Education. During the academic year 1945/1946, about 300.000 volumes were brought to Torun ${ }^{26}$. Among the transported books was, for example, the library of the former German Chancellor Otto von Bismarck from Warcin. A particularly valuable collection of books came from the University of Gryfia. The volumes were transported during the war by the Germans to Pęzino in order to protect them from the English bombing. A collection secured by the school authorities in Pasłęk was taken over by the director of the University Library in Torun, Stefan Burhardt, in the summer of 1946. The books came from the University Library in Königsberg. Among them were a dozen or so priceless silver bindings from the $16^{\text {th }}$-century Silver Library of Duke Albrecht of Prussia.

In the fall of 1945, a conference of district library inspectors was held in Pabianice ${ }^{27}$. During the meeting, the results of the protection of library collections were discussed, including those achieved by school authorities. The participants indicated encountered difficulties and the necessity to continue their works. Stanisław Sierotwiński proposed the creation of a representative office of the Ministry of Education that would conduct activities in the country. His plan was accepted by J. Grycz. The Ministry of Education Delegation was established in Kraków on December 1, 1945, its works were classified.

23 Zarządzenie Ministra Oświaty z dnia 9 lipca 1945 r. w sprawie przejęcia księgozbiorów podworskich od pełnomocników do spraw reformy rolnej, "Dziennik Urzędowy Ministerstwa Oświaty" 1945 , no 4, pos. 110.

24 Zarządzenie Ministra Oświaty z dnia 4 sierpnia 1945 r. w sprawie zabezpieczenia i zużytkowania księgozbiorów opuszczonych lub porzuconych, "Dziennik Urzędowy Ministerstwa Oświaty" 1945 , no 4, pos. 115 .

25 See: W. Kowalski, Sytuacja prawna poniemieckich zbiorów bibliotecznych w Polsce, "Przegląd Biblioteczny" 1997, no 1, pp. 17-23.

26 Archiwum Uniwersytetu Mikołaja Kopernika w Toruniu (Archives of Nicolaus Copernicus University in Toruń), Biblioteka UMK. Sprawozdania 1945/46-1946-47, ref. 74, p. 4 - Sprawozdanie Biblioteki Uniwersyteckiej w Toruniu za rok akademicki 1945/46.

27 Aktualne zagadnienia bibliotekarskie. Pierwsza Powojenna Konferencja Okręgowych Wizytatorów Bibliotek w dniach 24-27 października 1945 r. w Pabianicach, [ed. K.Ś.], Warszawa 1946. 
Information about the establishment of the institution was sent to ministries, voivodeship offices, and education offices. The tasks of the Delegation included searching for the so-called abandoned and deserted book collections, securing and caring for the collections, determining the nature of the secured books and presenting the Ministry of Education with suggestions regarding their allocation. The central authorities, on the basis of written permits, decided on the distribution of books. The Delegation was managed by S. Sierotwiński, who was responsible for supervising the country's territory divided into six districts. Until the end of December 1946, with a relatively small team of around 30 people, S. Sierotwiński protected 5,462,704 volumes all over the country. He secured the greatest number of books, i.e. 2,023,337 volumes, in Lower Silesia. 68,000 volumes from district I Kraków, 1,682,337 volumes from district II Wrocław, and 43,367 volumes from district VI Lublin were brought to Kraków and secured on the spot. No books were brought from the distant districts, i.e. III Szczecin, IV Gdańsk and V Olsztyn. S. Sierotwiński encountered numerous difficulties at work, including those on the part of the Citizens' Militia. At the end of 1946, he proposed the establishment of several warehousing/sorting centres in the country. His idea was approved by the General Director of Libraries, J. Grycz. Thus, the second stage of the post-war protection of library collections in Poland began.

On February 1, 1947, the Ministry of Education established warehousing/ sorting centres for protected book collections in seven cities: Gdańsk, Katowice, Kraków, Poznań, Szczecin, Torun and Wrocław. The legal basis for the establishment of the centres was a letter from the Head Office of Libraries of the Ministry of Education of January 1946. The centres were managed by: Karol Badecki, Aleksander Birkenmajer, Stefan Burhardt, A. Knot, Marian Pelczar, Maria Quirini and Franciszek Szymiczek. The managers reported directly to the Ministry of Education. They performed their work on the basis of the instruction of January 25, 1946, concerning works with protected book collections ${ }^{28}$, prepared by J. Grycz. The document made it possible to determine the number of books and their initial segregation. Earlier, in a hurry, the protected and transported books were converted into kilograms, tons, railway carriages, horse carts, car platforms, boxes, bags, cubic meters, and even estimated "by eye". A form developed on the basis of the instruction of January 25, 1946, facilitated the works. The employees of the warehousing centres divided books into historic and special ones, scientific literature divided into sections and other groups (magazines, popular science, fiction, literature for children and youth, and regional prints). In special collections, polonica were distinguished. It was

28 Instrukcja z dnia 25 stycznia $1946 \mathrm{r}$. w sprawie postępowania z księgozbiorami zabezpieczonymi, "Dziennik Urzędowy Ministerstwa Oświaty” 1946, no 1, pos. 13. 
necessary to record the number of works published in Polish, German and other languages in case of scientific literature and other groups. The form was used while segregating the works from the storerooms of the warehousing centres for protected book collections. In total, more than ten million volumes were protected until 1949. After the initial segregation, a process began to compile and include the works in book collections. The Ministry of Education decided on the division of books. The distributed collections were dispersed, which was an inevitable phenomenon in post-war Poland.

The secured collections included books looted by the Germans during the war in other European countries and transported to Poland during the occupation ${ }^{29}$. Representatives from other countries were coming in search of volumes. Until 1948, the Ministry of Education, as a result of instructions from J. Grycz, gave consent for the transfer of works to the rightful owners. Later, for political reasons, the returns ceased. At the beginning of 1949, J. Grycz was dismissed from work at the Ministry of Education for the approval of the return of library collections of Belgian and Dutch provenance.

\section{Conclusions}

According to the conducted research, there were few legal regulations concerning post-war protection of written heritage in Poland. The most important legislative documents were drafted by J. Grycz, whose plan contributed to coordinated and centralized actions throughout the country. As a result of the actions taken, over ten million volumes were secured in Poland in the years 1944-1949, most of them post-German. Under Polish law, library collections, regardless of their origin, were treated equally. A relatively small group of people started saving valuable works which was not an easy and satisfying job. They constantly faced numerous difficulties and challenges. The saved collections were distributed, used to partially compensate for war losses and to rebuild libraries and librarianship in Poland.

\section{Bibliography}

Source materials

- Manuscripts

Archiwum Biblioteki Jagiellońskiej w Krakowie (Archive of the Jagiellonian Library in Kraków)

29 See: R. Nowicki, Rola..., pp. 198-203. 
Legal regulations concerning the preservation and protection of library collections...

Archiwum Delegata Ministerstwa Oświaty do zabezpieczenia księgozbiorów opuszczonych i porzuconych. Rozporządzenia i ich odpisy 1945.

Archiwum Biblioteki Uniwersyteckiej w Poznaniu (Archives of the University Library in Poznań)

Referat Zabezpieczenia i Segregacji Zbiorów. Zarządzenia, instrukcje, upoważnienia 1944-1946, sygn. 535.

Archiwum Uniwersytetu Mikołaja Kopernika w Toruniu (Archives of Nicolaus Copernicus University in Toruń)

Biblioteka UMK. Sprawozdania 1945/46-1946-47, sygn. 74.

Archiwum Uniwersytetu Wrocławskiego (Wrocław University Archives)

Biblioteka Uniwersytecka 1945-1953, ref. R-30, p. 418.

Wojskowe Biuro Historyczne (Centralne Archiwum Wojskowe) w Warszawie (Military Historical Bureau - Central Military Archives - in Warsaw)

Sygn. III.5.197, Rozkaz no 120 Naczelnego Dowódcy Wojska Polskiego z 22 XI $1944 \mathrm{r}$.

- Printed materials

Aktualne zagadnienia bibliotekarskie. Pierwsza Powojenna Konferencja Okręgowych Wizytatorów Bibliotek $w$ dniach 24-27 października 1945 r. w Pabianicach, [ed. K.Ś.], Warszawa 1946.

Grycz J., Wskazówki dla prowadzacych akcję zabezpieczenia bibliotek i zbiorów bibliotecznych, Warszawa-Poznań 1945.

- Legal documents

Ustawa z dnia 6 V 1945 r. o majątkach opuszczonych i porzuconych, "Dziennik Ustaw" 1945, no 17, pos. 97.

Dekret z dnia 8 III 1946 r. o majątkach opuszczonych i poniemieckich, "Dziennik Ustaw" 1946 , no 13 , pos. 87.

Dekret z dnia 17 IV1946 r. o bibliotekach i opiece nad zbiorami bibliotecznymi, "Dziennik Ustaw" 1946, no 26, pos. 163.

Zarządzenie Ministra Oświaty z dnia 9 lipca 1945 r. w sprawie przejęcia księgozbiorów podworskich od pełnomocników do spraw reformy rolnej, "Dziennik Urzędowy Ministerstwa Oświaty" 1945, no 4, pos. 110.

Zarządzenie Ministra Oświaty z dnia 4 sierpnia 1945 r. w sprawie zabezpieczenia i zużytkowania księgozbiorów opuszczonych lub porzuconych, "Dziennik Urzędowy Ministerstwa Oświaty” 1945, no 4, pos. 115.

Okólnik Resortu Oświaty w sprawie zabezpieczenia bibliotek i zbiorów bibliotecznych, Nr Bibl. IV-W-2195/44, “Dziennik Urzędowy Resortu Oświaty” 1944, no 1-4, pos. 32. Instrukcja z dnia 25 stycznia 1946 r. w sprawie postępowania z księgozbiorami zabezpieczonymi, "Dziennik Urzędowy Ministerstwa Oświaty” 1946, no 1, pos. 13. 
Wezwanie do nauczycielstwa polskiego, “Dziennik Urzędowy Resortu Oświaty” 1944, no $1-4$.

Literature

Knot A., Polskie prawo biblioteczne, Wrocław-Warszawa 1947.

Kowalski W., Sytuacja prawna poniemieckich zbiorów bibliotecznych w Polsce, "Przegląd Biblioteczny" 1997, no 1, pp. 17-23.

Mężyński A., Józef Grycz (1890-1954) organizator polskiego bibliotekarstwa, Warszawa 2020.

Mężyński A., Z dziejów bibliotek w Polsce. Od średniowiecza do 1989 roku, Warszawa 2017.

Nowicki R., Działalność Aleksandra Birkenmajera na rzecz powojennej ochrony zbiorów bibliotecznych. Ziemie zachodniej i pótnocnej Polski w latach 1945-1947, Poznań 2006.

Nowicki R., Działalność krakowskiej Delegatury Ministerstwa Oświaty do zabezpieczenia księgozbiorów opuszczonych i porzuconych na Pomorzu Zachodnim, [in:] Ochrona zbiorów bibliotecznych, ed. by R. Nowicki, J. Gomoliszek, K. Wodniak, Bydgoszcz 2016, pp. 85-96.

Nowicki R., Nieznany projekt rozporządzenia o zabezpieczeniu zbiorów bibliotecznych i odbudowie bibliotek w powojennej Polsce, "Z Badań nad Książką i Księgozbiorami Historycznymi” 2012, vol. 6, pp. 113-126.

Nowicki R., Powojenna ochrona zbiorów bibliotecznych w Polsce w latach 1944-1955. Wybór źródel, Bydgoszcz 2013.

Nowicki R., Protection of written heritage after World War II. Józef Grycz's contribution to saving library collections, "Studies into the History of the Book and Book Collections" 2019, special issue: For an Independent Poland, pp. 191-206.

Nowicki R., Rola Józefa Grycza w powojennej ochronie zbiorów bibliotecznych, “Z Badań nad Książką i Księgozbiorami Historycznymi” 2011, vol. 5, pp. 89-108.

Nowicki R., Rola Katowickiej Zbiornicy Księgozbiorów Zabezpieczonych w powojennej ochronie zbiorów bibliotecznych w Polsce, Bydgoszcz 2015.

Pietrzkiewicz D., Spory o zbiory. Piotr Bańkowski - rewindykacja i ochrona dziedzictwa piśmienniczego, Pułtusk-Warszawa 2019.

Puchalski J., Źródła do historii bibliotek w Polsce w latach 1918-1947. Studium bibliologiczne, Warszawa 2007.

Zarzębski T., Polskie prawo biblioteczne 1773-1990, Warszawa 1991. 